\title{
An in vitro globin gene switching model based on differentiated embryonic stem cells
}

\author{
Michael H. Lindenbaum and Frank Grosveld \\ Laboratory of Gene Structure and Expression, National Institute for Medical Research, London NW7 1AA UK
}

\begin{abstract}
We used mouse embryonic stem (ES) cells to study globin gene expression and switching in vitro. We show that ES-derived embryoid bodies express the full complement of mouse embryonic globin genes in the correct temporal order and that on further differentiation, a switch occurs to the fetal/adult genes. In addition, the erythroid-specific transcription factor NF-E1 was shown to be expressed coordinately with that of globin in embryoid bodies. We conclude from these experiments that the ES cell system provides a good model to study hematopoietic development. When the human $\epsilon$ - or $\beta$-globin genes driven by the dominant control region (DCR) are introduced into this system, the human $\epsilon$-globin gene, in contrast to the $\beta$-globin gene, is not deregulated by the presence of the DCR and is expressed strictly as an embryonic gene. We conclude from this that the $\epsilon$-globin gene is not regulated by competition with other genes in the human $\beta$-globin locus.
\end{abstract}

[Key Words: ES cells; erythroid differentiation; globin switching]

Received July 5, 1990; revised version accepted October 9, 1990.

The human $\beta$-globin gene cluster consists of a group of genes that are expressed in a stage-specific manner in the erythroid compartment. The locus spans a region of $70 \mathrm{~kb}$, containing five highly conserved genes and their regulatory sequences in the order $5^{\prime}-\epsilon, \gamma^{\mathrm{G}}, \gamma^{\mathrm{A}}, \delta, \beta-3^{\prime}$, as well as the recently described dominant control region (DCR), which confers high-level, position-independent expression of globin genes in transgenic mice (Grosveld et al. 1987).

The $\epsilon$-globin gene is expressed during human embryonic life and is localized to a population of primitive nucleated erythroid cells originating in the yolk sac blood islands (Peschle et al. 1985) These persist for only a short period as a site of erythropoiesis. At between 5 and 10 weeks of gestation the major site of erythropoiesis shifts to the liver (Rifkind et al. 1969), $\epsilon$-globin gene expression is switched off, and $\gamma$-globin becomes the predominantly expressed species within definitive non-nucleated erythrocytes. The mechanism for $\epsilon$-globin silencing remains unclear, although some evidence points to elements immediately $5^{\prime}$ to the gene as being important in this regard (Cao et al. 1989; Lamb et al. 1989). Prior to the time of birth, hemopoiesis shifts to the bone marrow, and postnatally, the $\gamma$-globin genes are downregulated and $\beta$-globin becomes the predominant species. Unlike the $\epsilon$-globin gene, the $\gamma$-globin genes are not inactivated permanently and they can be expressed in the adult under certain conditions or in particular hemoglobinopathies (for review, see Poncz et al. 1989). By analogy with the data obtained for the chicken $\beta$ - and $\epsilon$-globin genes (Choi and Engel 1988), the fact that the developmental expression of the human $\gamma$ - and $\beta$-globin genes is affected by the presence of the DCR has led to the suggestion that at least the $\gamma$ - and $\beta$-globin genes are regulated partly by gene competition within the domain (Blom van Assendelft et al. 1989; Behringer et al. 1990; Enver et al. 1990).

In terms of both genomic organization and developmental sequence of expression, the mouse $\beta$-globin locus differs somewhat from that of the human. It spans $>65 \mathrm{~kb}$, consisting of five actively transcribed genes, $5^{\prime}-\epsilon_{\mathrm{y},}, \beta_{\mathrm{h} 0}, \beta_{\mathrm{h} 1}, \beta_{\mathrm{mai}}, \beta_{\min }-3^{\prime}$, as well as two pseudogenes, $\beta_{\mathrm{h} 2}$ and $\beta_{\mathrm{h} 3}$ (Jahn et al. 1980; Leder et al. 1980). At 8 days of gestation, the embryonic $\beta_{\mathrm{hl}^{-}}$and $\epsilon_{\mathrm{y}}$-globin genes begin to be expressed in nucleated cells of the yolk sac blood islands (Fantoni et al. 1968, 1969; Kovach et al. 1967; Hansen et al. 1982; Farace et al. 1984). These cells are released into the embryonic circulation at day 9-10 (Kovach et al. 1967), and $\epsilon_{\mathrm{y}}$ mRNA expression can be detected in circulation until about day 16 /Whitelaw et al. 1989). At day 10.5 of gestation, the fetal liver becomes the major site of erythropoiesis almost until birth (Rifkind et al. 1969). The non-nucleated erythrocytes are released into circulation at 12-13 days of gestation and express the fetal/adult $\beta_{\text {mai }}$ and $\beta_{\min }$ forms of globin (Konkel et al. 1979). At 16-17 days of gestation, the spleen and bone marrow become the major sites of erythropoiesis and remain so throughout adult life (Borghese 1959). Thus, in the mouse, a unique fetal form of $\beta$-like globin does not exist, in contrast with the human fetus where $\gamma$-globin is expressed in erythrocytes that develop predominantly but not exclusively in the fetal liver.

We sought to develop a system that would enable us 
to study the events at the embryonic stages of hematopoietic development and erythropoiesis in vitro. To this end we made use of mouse embryonic stem cells (Evans and Kaufman 1981; Martin 1981). These cells, which are derived from the inner cell mass of cultured blastocysts, can remain totipotent when maintained for long periods in culture. However, when grown in suspension, they aggregate to form embryoid bodies, which contain hematopoietic cells among various differentiated lineages (Doetschman et al. 1985). We demonstrate that on differentiation of embryonic stem (ES) cells into embryoid bodies, an erythropoietic differentiation program ensues within these embryoid bodies, which is similar both temporally and in terms of the sequence of globin gene expression to that observed in early mouse embryos. We used ES cells transfected with a human $\epsilon$ - or $\beta$-globin gene in the presence of a DCR to show that ES cells provide a good in vitro model system to study human globin gene switching and allow us to conclude that $\epsilon$-globin gene expression and suppression is not influenced by either the presence of the DCR or any of the other globin genes within the same gene domain.

\section{Results \\ Globin gene expression and switching in ES cell-derived embryoid bodies}

To examine the process of embryonal erythropoiesis and globin gene expression, we exploited the observations of Doetschman et al. (1985), who first demonstrated that mouse ES cells can be made to undergo differentiation in vitro, giving rise to various lineages in the embryoid

A)
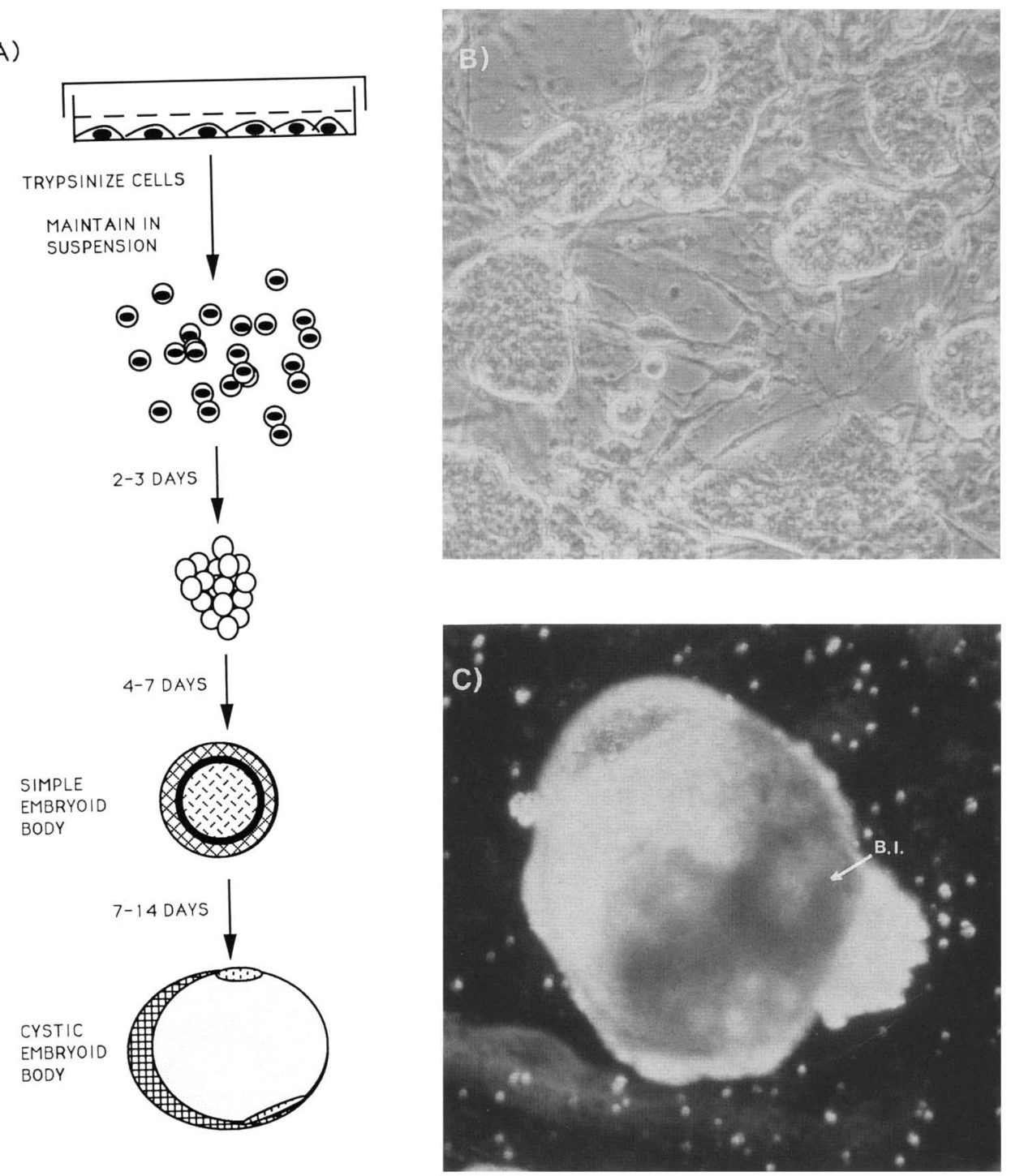

Figure 1. Formation of embryoid bodies from ES cell cultures. $|A|$ Flowchart summarizing the steps in the establishment of ES-derived embryoid bodies. (For detailed procedure, see Materials and methods.) (B) Undifferentiated CCE-ES cells growing on a confluent monolayer of STO fibroblasts. Note that the stem cells grow in characteristic compact colonies. (Magnification, $195 \times) .(C)$ Cystic embryoid body with visible blood island after culture for 9 days (Magnification, $38 \times$ ). 
bodies. Initially, the ES cell differentiations were carried out by performaning limited trypsinization on ES cultures maintained for one passage in the absence of a feeder layer (Robertson 1987). Such treatment results in the formation of ES cell aggregates which, over a 2-week period, give rise to cystic embryoid bodies (Fig. 1), some of which contain visible blood islands $(10 \%)$ and/or beating myocardium (up to $50 \%$ ). RNA was isolated at various times up to 18 days of the differentiation process and analyzed for the presence of globin transcripts by S1 nuclease protection. The transcripts for the embryonic mouse $\beta$-like globins $\beta_{\mathrm{hl}}$ and $\epsilon_{\mathrm{y}}$ and the $\alpha$-like globin gene $\zeta$ were detectable between days 10 and 18 of culture (data not shown), confirming earlier findings at the protein level (Doetschman et al. 1985). Northern blot analysis confirmed the presence of full-length globin transcripts, and the appearance of globin transcripts correlated with the presence of visible blood islands in the cystic embryoid bodies (data not shown). Interestingly, transcripts of the fetal/adult $\alpha$ - and $\beta$-globin genes could also be detected, but during an overlapping time period (not shown). Thus, it appeared that the entire complement of mouse globin genes is expressed in ES-derived embryoid bodies and that the ES cell system is capable (at least partly) of carrying out the switch from the embryonic to the fetal expression pattern. However, these initial experiments did not demonstrate whether $\beta_{\mathrm{h} 1}$ or $\epsilon_{\mathrm{y}}$ expression can be shut off and be replaced by $\beta_{\mathrm{maj}}$ expression in late embryoid bodies, which is what would be expected if a switch has occurred.

Although globin expression could be demonstrated in cystic embryoid bodies, it was found that the onset and extent of globin transcription was quite variable (data not shown). This made it impossible, for example, to detect any differences in the timing of expression of the embryonic $\beta$-globin genes $\beta_{\mathrm{h} 1}$ and $\boldsymbol{\epsilon}_{\mathrm{y}}$, which are known to be expressed at different but overlapping time periods, with $\beta_{\mathrm{h}}$ preceding $\epsilon_{\mathrm{y}}$ (Farace et al. 1984; Chada et al. 1986; Whitelaw et al. 1989). This was probably due to the size heterogeneity of the starting ES cell aggregates. Therefore, we used an alternative method to create embryoid bodies (Doetschman et al. 1985; Gossler et al. 1986|, which uses as starting material a single cell suspension of ES cells (Fig. 1; for details, see Materials and methods). When normal (not shown) or transfected ES cells (Figs. 2A and 6A, below) are differentiated to embryoid bodies in this way, they showed earlier and more reproducible onset of globin transcription as well as higher overall levels of globin expression; thus, this method was employed routinely as the method of choice in ES cell transfection experiments. Figure 2A shows that even the different expression times of the embryonic genes $\beta_{\mathrm{hl}}$ and $\epsilon_{\mathrm{y}}$ can be distinguished, with $\epsilon_{\mathrm{y}}$ appearing slightly earlier and disappearing faster than the $\beta_{\mathrm{h} 1}$ transcripts. Both are almost completely suppressed by 15 days, to be replaced by the $\beta_{\text {maj }}$ signal, albeit at low levels. Almost always a recurrence of embryonic transcripts is observed at 21 days, which we attribute to the growing and differentiation of new embryoid bodies. A clear switch is observed for the $\zeta$ and $\alpha$ genes (Fig. 2B); they are coexpressed as early as day 6 (with $\zeta$ slightly higher than $\alpha$ ), whereas $\alpha$ is clearly the predominant species by day 15 .

\section{Globin gene expression follows expression of NF-E1 in embryoid bodies}

NF-El is a transcription factor found at high levels in erythroid cells as well as megakaryocytes (Martin et al. 1990; Romeo et al. 1990) and may be involved in regulating the transcription of numerous erythroid-specific genes, including the human (deBoer et al. 1988; Wall et al. 1988) and chicken (Evans et al. 1988) $\beta$-globin genes. To assess its importance during early erythropoiesis, RNA from several differentiation series from untransfected (not shown) and transfected ES cells (Figs. 2 and 4, below) was subjected to Northern blot analysis, as described in Materials and methods. The Northern blot was probed sequentially with a partial mouse NF-El cDNA probe (E. deBoer and P. Belhumeur, unpubl.), a mouse $\alpha$-globin probe and, finally, a probe detecting the 18S rRNA subunit (Bakken et al. 1982). The results of this analysis are shown in Figure 3. As can be seen in Figure 3A, NF-E1 transcripts are detectable at low levels in undifferentiated ES cells. However, mRNA levels rise dramatically at days 6 and 9 of differentiation, which precedes slightly, but overlaps the peak of globin synthesis in these embryoid bodies (Fig. 3B; see also Figs. $2 \mathrm{~A}, \mathrm{~B}$ and $5 \mathrm{~A}$, below). Thus, globin gene expression follows the timing and relative levels of NF-El expression in embryoid bodies, suggesting that NF-E1 is required during all stages of development of the erythroid lineage. However, the fact that the total level of NF-E1 follows the levels of globin RNA at all stages suggests that although required, it may not be instrumental in the process of developmental switching.

\section{Expression of human $\beta$-globin genes in embryoid bodies}

To assess the potential of ES-derived embryoid bodies as a system with which to examine cis-acting sequences important in directing stage-specific expression of human $\beta$-globin genes, undifferentiated ES cells were transfected with human minilocus $\epsilon$ - and $\beta$-globin gene constructs. This $\epsilon$-globin construct contained both $5^{\prime}-$ and $3^{\prime}$-hypersensitive sites of the $\beta$-globin DCR /Grosveld et al. 1987) and was derived from the minilocus $\beta$ globin construct (Blom van Assendelft et al. 1989) by deletion of the $\mathrm{Cla}-\mathrm{Kpn} \beta$-globin fragment and insertion of the 2.8- $\mathrm{kb} \mathrm{Cla}-\mathrm{Kpn}$ fragment containing the human e-globin gene. It should be noted that this contains the entire native $21-\mathrm{kb}$ human sequence $5^{\prime}$ of the $\epsilon$-globin gene (Fig. 4C). Four G-418-resistant clones were selected after transfection, differentiated, and characterized by Southern blots of the DNA and S1 nuclease protection analysis of RNA (Fig. 4A,B). The RNA samples for each of the human $\epsilon$-globin-bearing clones represent the time points in a differentiation series at which the levels of human $\epsilon$-mRNA were at their peak, which results in a clone-to-clone variation in the ratio of mouse $\epsilon_{\mathrm{y}} / \beta_{\mathrm{h} 1}$, because the different cultures are not completely synchro- 

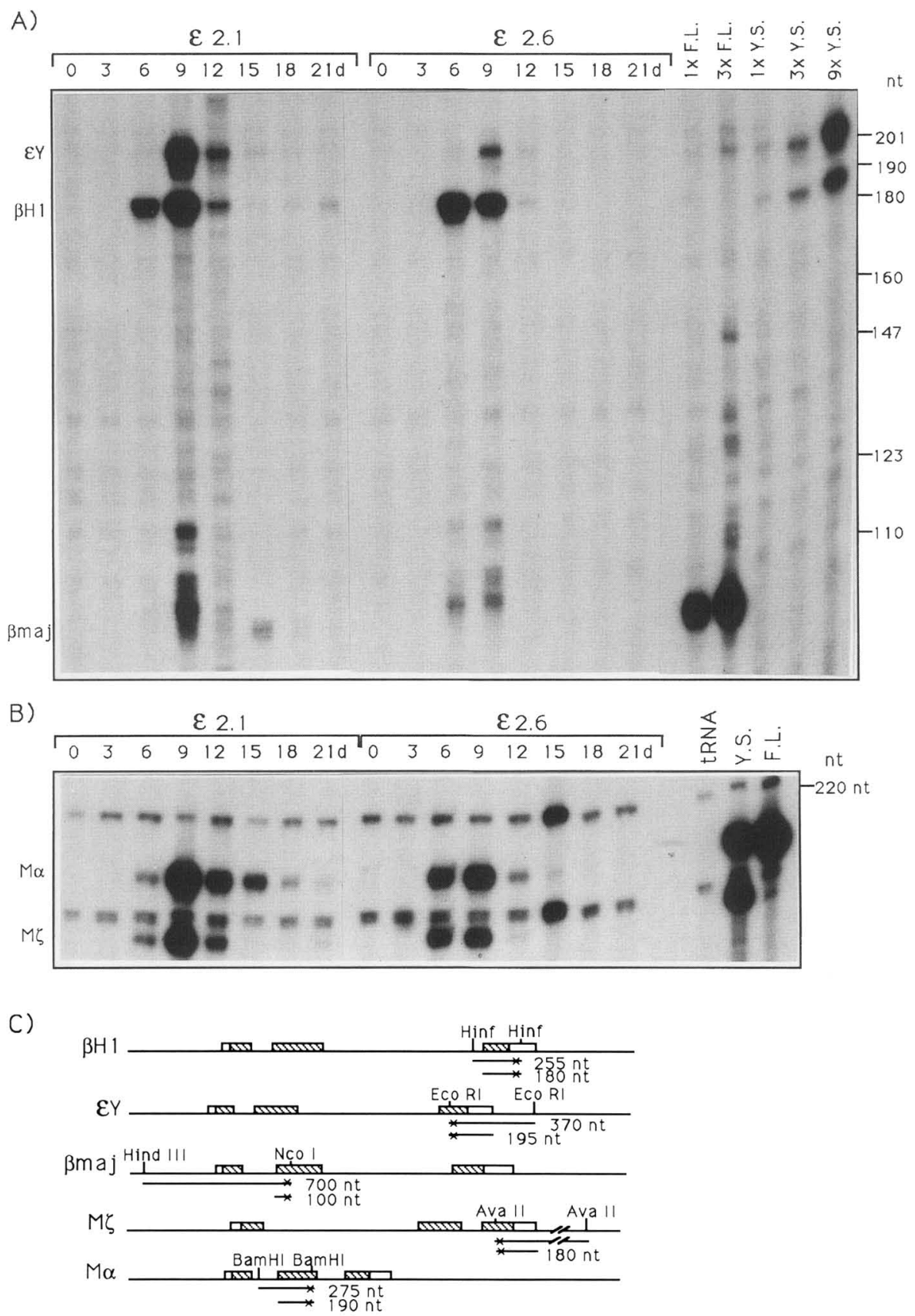

Figure 2. Expression of endogenous globin genes in embryoid bodies derived from ES clones $\epsilon 2.1$ and $\epsilon 2.6$. (A) Total RNA (20 $\mu \mathrm{g}$ ) from undifferentiated cells $\{0\rangle$ or embryoid bodies derived from clones $\epsilon 2.1$ and $\epsilon 2.6$ maintained in culture for up to 21 days was hybridized to a mixture of mouse $\epsilon \mathrm{Y}, \beta_{\mathrm{h} 1}$, and $\beta_{\mathrm{maj}}$ end-labeled probes adjusted to equal specific activities. Control RNA samples include 16-day mouse fetal liver (1 and $3 \mu \mathrm{g})$ as well as 10.5 -day mouse yolk sac $(1,3$, and $9 \mu \mathrm{g})$. Protected fragments are indicated at left. (B) RNA samples hybridized as in $A$ to mouse $\alpha$ - and $\zeta$-globin end-labeled probes adjusted to equal specific activity. The bands present in all lanes are undigested input probes. $(C)$ Probes and protected fragments of Sl nuclease protection assays are as described in $A$ and $B$.

nous. Because probe-specific activities were adjusted to be identical and probes were in excess, the signals of the protected mRNA fragments reflect their relative abundance. High-level expression of human $\epsilon$-globin is seen in all four clones, and the peak levels of human $\epsilon$-globin mRNA relative to the endogenous embryonic globin genes reflect the copy numbers of the individual clones. Furthermore, the expression of the transgene in all clones was coordinately regulated with the endogenous embryonic gene (data not shown). Two clones, $€ 2.1$ with a moderate $(15-20)$ copy number and $\epsilon 2.6$ with a high (50-100) copy number of the transfected gene, are shown in detail. As can be seen for both clones (Fig. $5 \mathrm{~A}, \mathrm{~B})$, human $\epsilon$-globin gene expression is linked tightly to that of the endogenous embryonic globin genes, and no message can be detected in undifferentiated ES cells. 

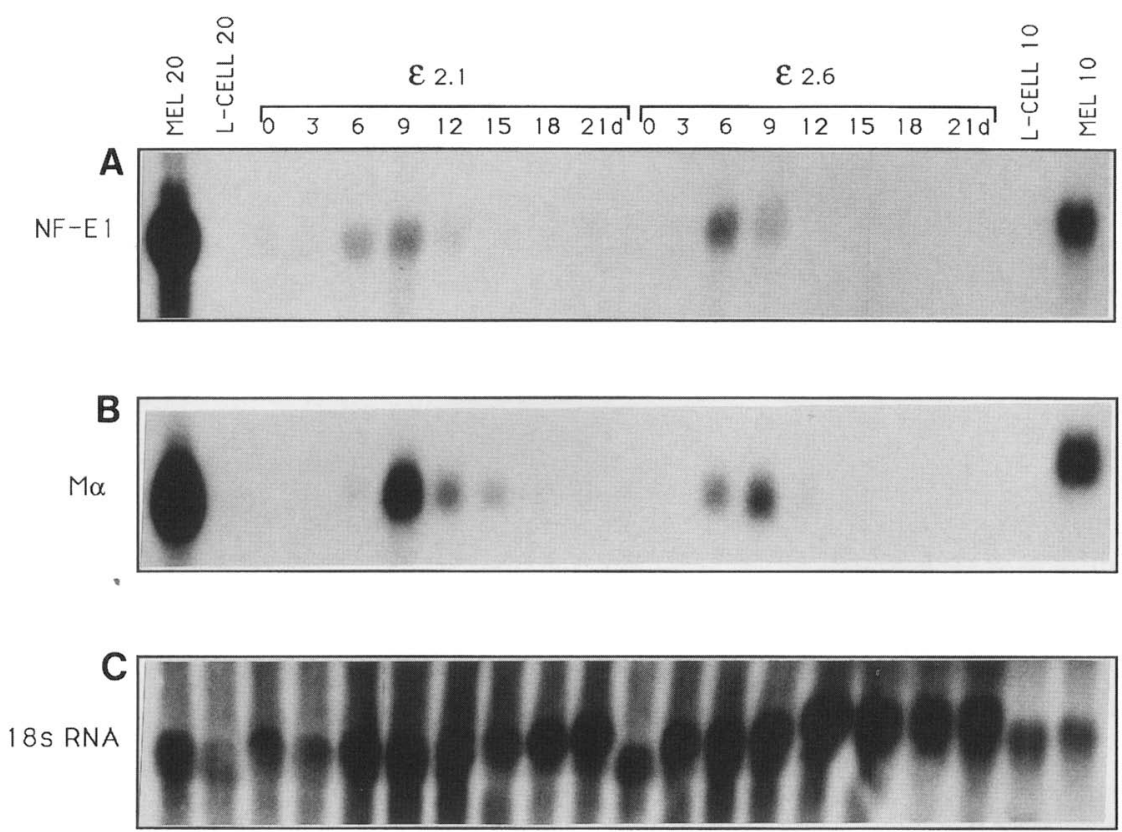

Figure 3. Northern blot analysis of NF-E1 expression in embryoid bodies. Total RNA $(20 \mu \mathrm{g})$ from $\epsilon 2.1$ and $\epsilon 2.6$ differentiation series (see Figs. 4 and 5) was fractionated on a $1 \%$ formaldehyde/ agarose gel, blotted onto nylon membrane, and probed sequentially with a mouse NF-E1 cDNA fragment, a mouse $\alpha$ fragment, and an 18S RNA probe. Control samples include total MEL cell RNA (10 and $20 \mu \mathrm{g}$ ) and total L-cell RNA (10 and 20 $\mu \mathrm{g})$. Exposure times for blots were $20 \mathrm{hr}$ for NF-E1, $6 \mathrm{hr}$ for $\alpha$-globin, and $1 \mathrm{hr}$ for $18 \mathrm{~S}$ rRNA.
Although expression of human $\epsilon$-globin and $\beta_{\mathrm{h} 1}$ are both detectable at day 6, 3 days earlier than $\epsilon_{y}$ for both clones, the temporal pattern of human $\epsilon$ expression resembles that of $\epsilon_{\mathrm{y}}$ rather than $\beta_{\mathrm{h} 1}$. The human $\epsilon / \epsilon_{\mathrm{y}}$ ratio of clone $\epsilon 2.1$ at days 6,9 , and 12 is more constant than the increasing human $\epsilon / \beta_{\mathrm{hl}}$ ratio over the same period. Similarly, in clone $\epsilon 2.6$, the levels of $\epsilon_{\mathrm{y}}$-globin transcripts increase from day 6 to day 9 , as do those of human $\epsilon$-globin mRNA /cf. with the lower exposure of human $\epsilon$-globin signal in Fig. 5B), whereas the levels of $\beta_{\mathrm{h} 1}$ mRNA clearly decrease over the same period. Interestingly, the high levels of human $\epsilon$-globin RNA in clone $\epsilon 2.6$ appear to suppress the levels of $\epsilon_{\mathrm{y}}$ mRNA but not those of $\beta_{\mathrm{hl}}$. This is probably related to the imbalanced expression of $\epsilon$-globin-type chains over $\alpha$-globin-type chains, resulting in cell loss analogous to the effect observed in transgenic mice, when high human $\alpha$ - or $\beta$-globin expression affects the level of endogenous $\alpha$ or $\beta_{\text {maj }}$ mRNA in the fetal liver (Grosveld et al. 1987; Hanscombe et al. 1989; Talbot et al. 1989). An additional feature of this high copy number expression concerns the inability of clone $\epsilon 2.6$ to express the $\beta_{\text {maj }}$ gene product. These observations may be indicative of the existence of alternate embryonic erythrocyte lineages with differing developmental potential (an $\epsilon_{y^{-}}$ type vs. a $\beta_{\mathrm{h} 1}$-type| but do not exclude the possibility that a sequential pattern of embryonic globin expression within one lineage is required before switching can occur. Alternatively, the high copy numbers of the transfected gene may lead to competition for specific factors, thereby suppressing endogenous genes differentially.

The $\beta$-globin gene minilocus (Fig. 6C) was also transfected into ES cells, and two G-418-resistant clones, $\beta 2.2$ and $\beta 2.3$, were characterized by Southern blot and $S 1$ nuclease protection assay (Fig. 6A,B). $\beta 2.2$ was found to have a fairly low copy number $(\sim 5)$, whereas $\beta 2.3$ was a higher copy number clone (>50 copies). Both clones were made to undergo in vitro differentiation, and RNA was prepared from embryoid bodies at 3-day intervals as described above. High-level expression of human $\beta$ globin mRNA could be detected in embryoid bodies derived from either clone $\beta 2.2$ or $\beta 2.3$, and mRNA levels appeared to relate to copy number in both cases (Fig. 6A). The onset of human $\beta$-globin expression did not correlate with $\beta_{\text {maj }}$ but could be detected at high levels at an earlier stage, coinciding with the onset of $\epsilon_{\mathrm{y}}$ expression. However, even though overall expression is high, the expression per copy of the human $\beta$-globin gene as compared to adult levels is low. At later stages, the expression pattern followed that of $\beta_{\text {maji }}$ after culture for 18 and 21 days, embryoid bodies of clone $\beta 2.2$ express mainly human $\beta$-globin and $\beta_{\text {maj }}$ mRNA but lower levels of $\beta_{\mathrm{h} 1}$ or $\epsilon_{\mathrm{y}}$ mRNA, showing the embryonic to fetal switch. The case of the high copy number $\beta 2.3$ is less clear; the highest levels of human $\beta$ expression are seen at day 15 of culture, which is also the peak of $\epsilon_{\mathrm{y}}$ expression. Thereafter, it tapers off but is clearly the predominant globin mRNA expressed at 18 and 21 days in culture. $\beta_{\text {maj }}$ mRNA can be detected at extremely low levels from day 15 onward, but it is difficult to determine whether the levels correlate with those of human $\beta$ mRNA. The high levels of human $\beta$-globin expression may result in a depletion of red cells reducing the levels of $\beta_{\text {maj }}$ similar to the anemia that has been demonstrated in high-copy transgenic fetuses (Grosveld et al. 1987; Hanscombe et al. 1989; Talbot et al. 1989). Alternatively, there could be a competition for a limiting transacting factor(s) resulting in a down-regulation of the mouse gene.

From these results, we conclude that human $\beta$-globin expression in embryoid bodies is regulated in a complex fashion, having both embryonic and fetal aspects. The 
A)

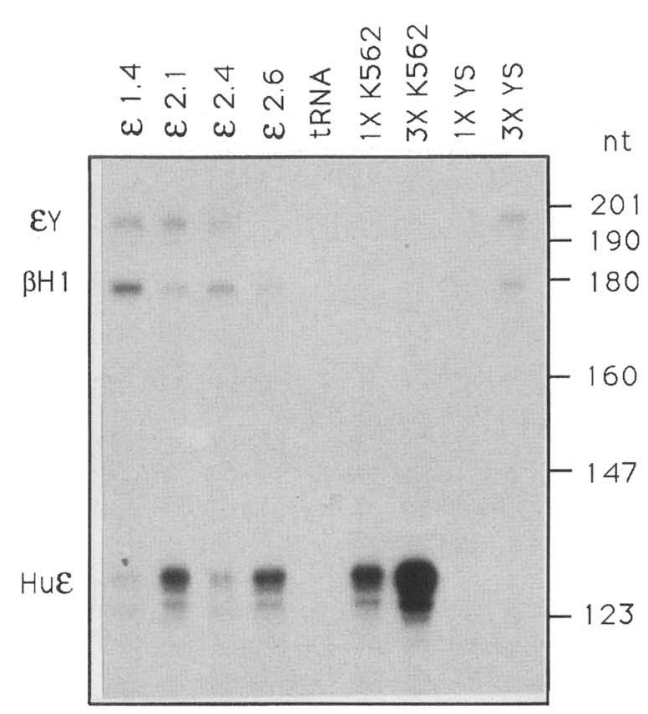

B)

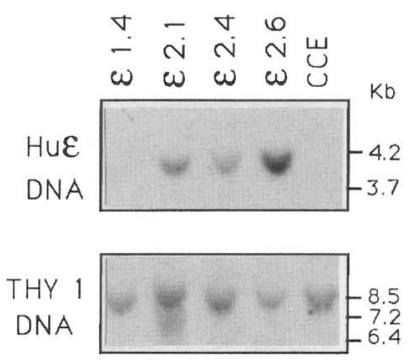

C)
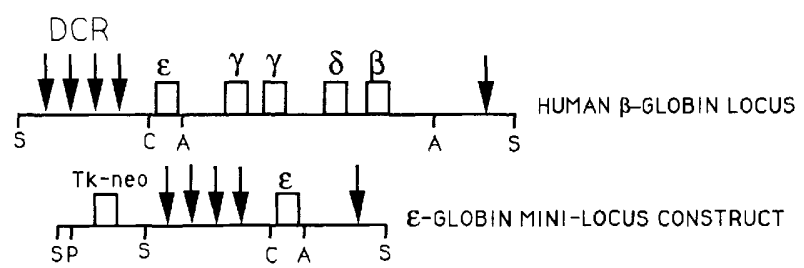

D)

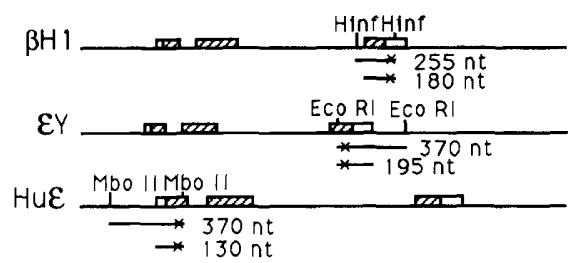

Figure 4. Analysis of ES cell clones transfected with human $€$ minilocus construct. $(A)$ Total RNA (10 $\mu$ g) isolated from embryoid bodies derived from G-418-resistant ES clones was hybridized to a mixture of mouse $\beta_{\mathrm{H}^{-}}, \epsilon \mathrm{Y}-$, and human $\epsilon$-globin end-labeled probes adjusted to equal specific activities. Control samples include K562 cell RNA (10 and $30 \mu \mathrm{g}$ ), 10.5-day yolk sac (2.5 and $7.5 \mu \mathrm{g}$ ), and tRNA $(10 \mu \mathrm{g})$. Protected fragments are indicated at left. $(B)$ Genomic DNA $(10 \mu \mathrm{g})$ isolated from clones described above and wild-type CCE-ES cells was digested with EcoRI, fractionated on a $0.6 \%$ agarose gel, and blotted onto nitrocellulose membranes. Southern blots were probed with a mixture of both an RsaI-BamHI fragment of the human $\epsilon$ gene, which detects a $3.8-\mathrm{kb} E c o \mathrm{RI} b a n d$ from the $\epsilon$ minilocus construct, and a mouse Thy 1.2, which detects an 8-kb EcoRI fragment derived from the endogenous mouse Thy 1.2 gene. Blots were washed to high stringency $\left(0.1 \times \mathrm{SSC}, 0.1 \% \mathrm{SDS}\right.$ at $\left.65^{\circ} \mathrm{C}\right)$ and exposed for $72 \mathrm{hr}(\mathrm{Thy} 1.2)$ or $14 \mathrm{hr}(\mathrm{human} \epsilon)$. (C) $\epsilon-\mathrm{Globin}$ minilocus construct transfected into ES cells. Vertical arrows indicate the positions of DNase I hypersensitive sites. Restriction sites

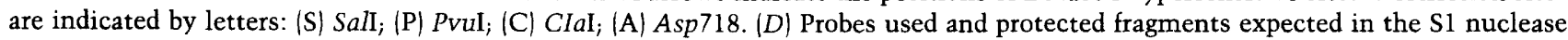
protection assay described in $A$. Asterisks $\left({ }^{*}\right)$ indicate position of labeling.

"aberrant" embryonic expression is probably caused by the presence of the DCR (see Discussion), but it seems clear that at later stages in embryoid bodies a switch has occurred to the fetal/adult globin stage expressing the endogenous $\beta_{\text {maj }}$ gene and high levels of the human $\beta$ transgene.

\section{Discussion}

Little is known about the relationship between the embryonic and fetal/adult erythrocyte compartments, and it remains an important question whether the embryonic and fetal compartments contain stem cells with the same or different developmental potential and whether these cells are derived from each other. Recent transplantation experiments have demonstrated the in vivo ability of yolk sac-derived progenitor cells to repopulate fetal W mutant mice (Toles et al. 1989). Thus, the embryonic yolk sac may give rise to hemopoietic stem cells with the ability to populate fetal/adult lineages. However, the detailed examination of this compartment is hindered by the lack of suitable in vitro models. In this work we describe a system based on differentiated ES cells that provides ready experimental access to this compartment and facilitates examination of these relationships. We demonstrated that when ES cells differentiate into cystic embryoid bodies, regulated expression of embryonic globin forms $\left(\epsilon_{\mathrm{y}}, \beta_{\mathrm{h} 1}, \zeta, \alpha\right)$ and NF-E1 can be detected easily at the RNA level, and in certain cases, a subsequent switch to the fetal/adult $\beta_{\text {maj }}$-globin form is seen. Globin expression in embryoid bodies correlates with the presence of visible blood islands in the cystic structures, and analysis of the protein content of these structures (Doetschman 1985) has demonstrated conclusively the presence of globin chains. 


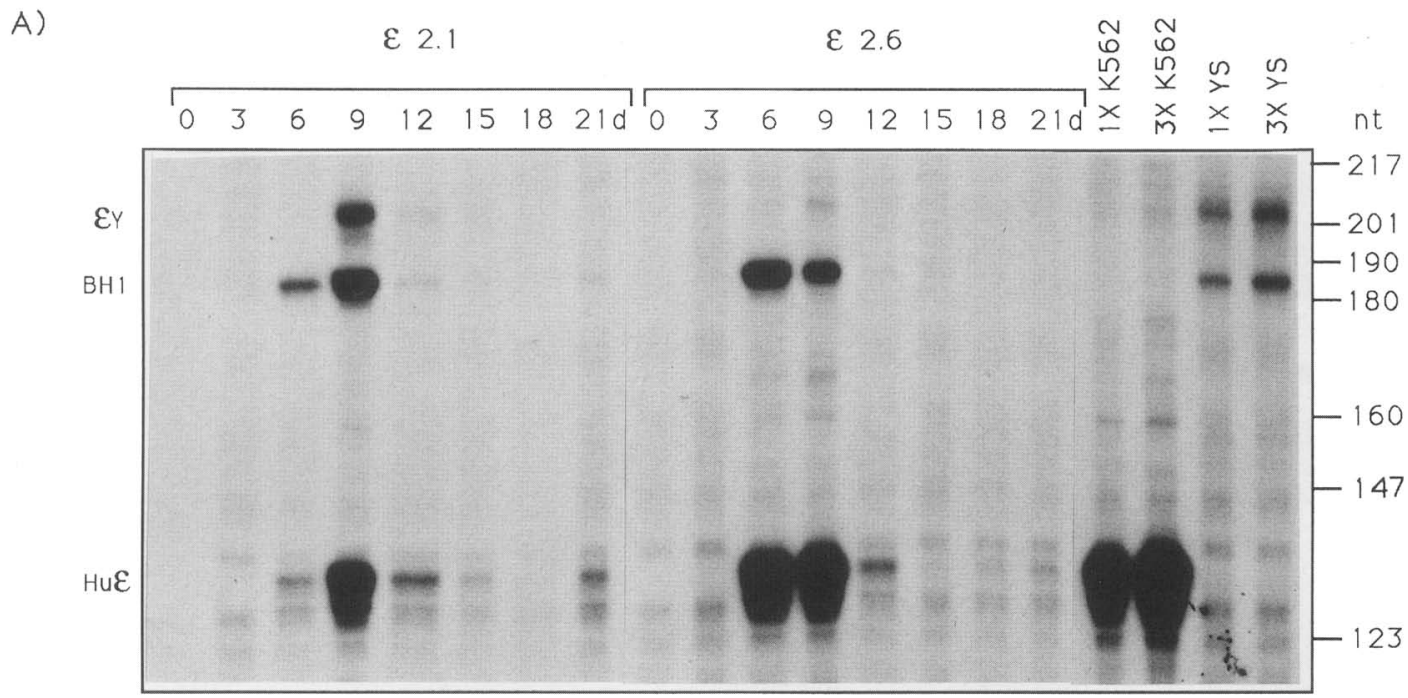

B)

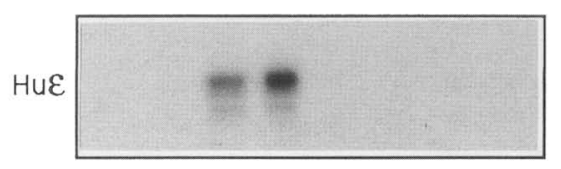

C)

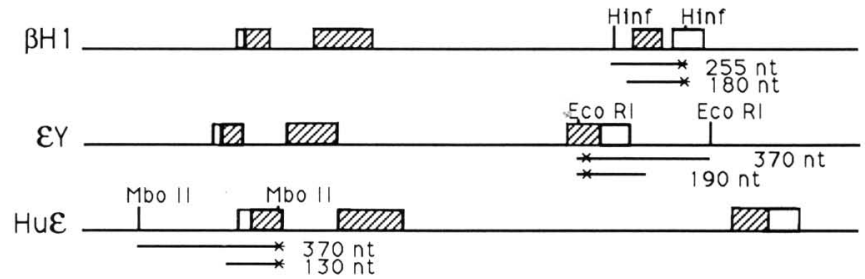

Figure 5. Expression of human $\epsilon$-globin mRNA in embryoid bodies derived from ES clones $\epsilon 2.1$ and $\epsilon 2.6$. $(A)$ Total RNA (20 $\mu g$ ) from undifferentiated cells $(0)$ and embryoid bodies derived from ES clones $\epsilon 2.1$ and $\epsilon 2.6$ maintained for up to 21 days in culture was hybridized to a mixture of mouse $\epsilon \mathrm{Y}, \beta_{\mathrm{h} 1}$, and human $\epsilon$-globin end-labeled probes, adjusted to equal specific activities. Control RNA samples include K562 cell total RNA (10 and $30 \mu \mathrm{g}$ ) and 10.5-day mouse yolk sac RNA (1 and $3 \mu \mathrm{g})$. Positions of protected fragments are indicated at left. Exposure was $15 \mathrm{hr}$. (B) Three-hour exposure of $A$ showing the profile of human $\epsilon$-globin expression in clone $\epsilon 2.6$. (C) Probes and protected fragments of S1 nuclease protection assays described in $A$ and $B$.

One potential problem with using ES cells is the fact that there is some heterogeneity to the synchrony of differentiation inherent in this methodology, such that, at a given time in culture, embryoid bodies may be of different size or complexity. However, in practice, this heterogeneity does not prove a serious handicap. In fact, we think the ES cells are a good model for the in vivo embryonic development for the following reasons. The onset of globin expression occurs between 6 and 9 days after the establishment of the cultures, which correlates well with the in vivo appearance of yolk sac blood islands (Fantoni et al. 1968, 1969; Kovach et al. 1967), and $\epsilon_{\mathrm{y}}$ expression was observed to lag behind that of $\beta_{\mathrm{h} 1}$, which has also been shown to be the case during embryonic development (Whitelaw et al. 1989). $\zeta$ mRNA expression in embryoid bodies was detected as early as 6 days of culture and was found to be coexpressed with $\alpha$ at this time. At later times, $\alpha$ became the predominant species, whereas $\zeta$ fell to barely detectable levels. During mouse embryonic development, $\zeta$, too, is coexpressed with $\alpha$ : There is no point in time when $\zeta$ is expressed exclusively (Whitelaw et al. 1989). Here, too, it seems that $\zeta / \alpha$ expression in embryoid bodies mimics the in vivo situation. Finally, in four of five experiments described in this work, $\beta_{\text {maj }}$ expression could be detected, albeit at low levels. In the case of the two high-copy human globin-containing clones $\beta 2.6$ and $\epsilon 2.3, \beta_{\text {maj }}$ expression may actually have been depressed due to expression of the transgene (see below). Nevertheless, it is not clear why the level and temporal pattern of $\beta_{\text {maj }}$ expression in embryoid bodies should be variable. Low $\beta_{\text {maj }}$ expression has been demonstrated in primitive erythrocytes of the yolk sac blood islands (Brotherton et al. 1979), and high levels of $\beta_{\text {maj }}$ expression are seen only after the shift to fetal liver as the hematopoietic organ has occurred. Perhaps, therefore, the low $\beta_{\text {maj }}$ levels seen in embryoid bodies reflect the limited capability of embryonic erythrocytes to express this globin form in an 

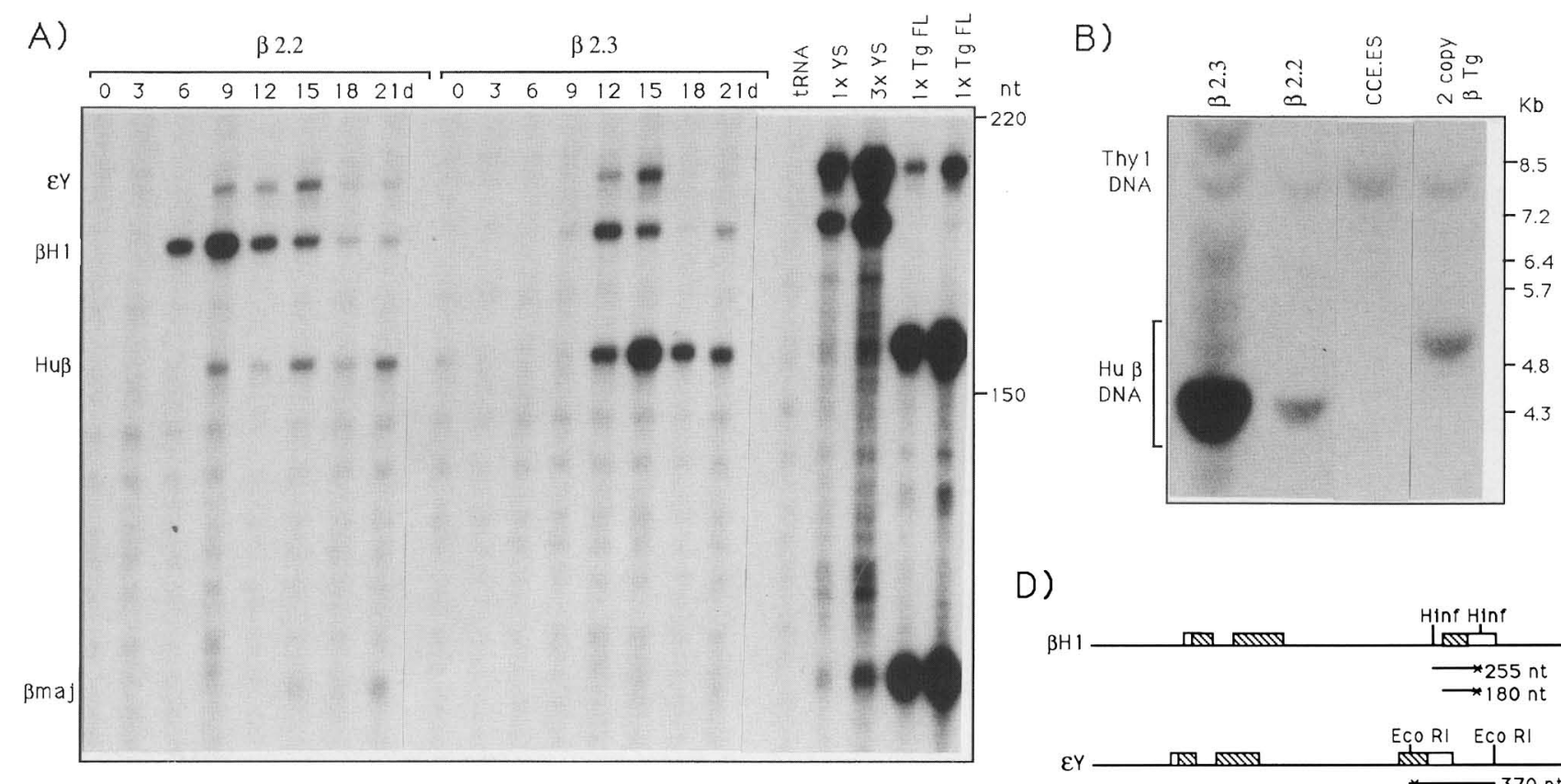

D)
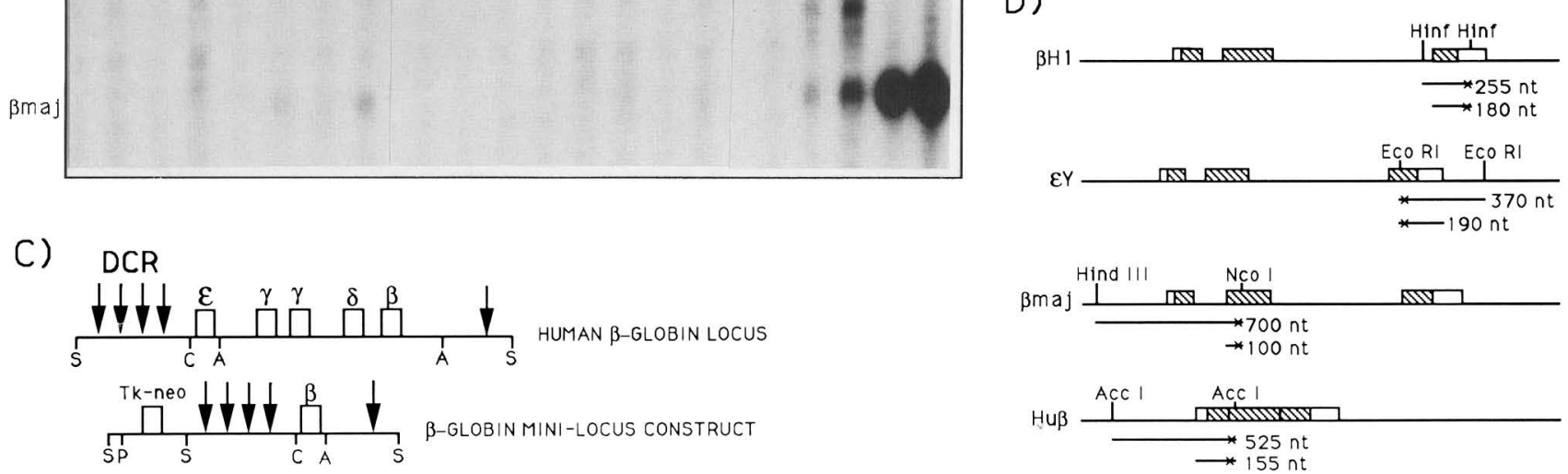

Figure 6. Analysis and expression of human $\beta$-globin in transfected ES clones $\beta 2.2$ and $\beta 2.3$. (A) Total RNA (20 $\mu \mathrm{g})$ from undifferentiated cells $(0)$ and embryoid bodies derived from ES clones $\beta 2.2$ and $\beta 2.3$ maintained for up to 21 days in culture were hybridized to a mixture of mouse $\epsilon_{\mathrm{y},} \beta_{\mathrm{hl}}, \beta_{\mathrm{maj}}$ and human $\beta$-globin end-labeled probes adjusted to equal specific activity. Control RNA samples include tRNA $(20 \mu \mathrm{g}), 10.5$-day mouse yolk sac $(1$ and $3 \mu \mathrm{g})$, and two-copy human $\beta$ transgenic mouse fetal liver $(1$ and $3 \mu \mathrm{g})$. The positions of protected fragments are indicated at left. $(B)$ Genomic DNA $(10 \mu \mathrm{g})$ from $\beta 2.2$, $\beta 2.3$, wild-type ES cells, and a two-copy human $\beta$-globin transgenic mouse were digested with EcoRI, fractionated on a $0.6 \%$ agarose gel, and blotted onto nitrocellulose. The blot was then probed with a $0.7-\mathrm{kb} B a m \mathrm{HI}-E c o \mathrm{RI}$ fragment of the human $\beta$ gene, which hybridizes to a 4.2 -kb EcoRI fragment derived from the $\beta$-minilocus construct, and a mouse Thy 1.2 probe, which detects an 8 -kb EcoRI fragment derived from the endogenous mouse Thy 1 gene. $(C)$ Diagram of the $\beta$-minilocus construct transfected into ES cells. Vertical arrows indicate DNase I hypersenitive sites. (S) SalI; (P) PvuI; (C) CIaI; (A) Asp718. (D) Probes and protected fragments of S1 nuclease protection assay described in $A$.

environment homologous to that of the yolk sac. It is clear from our results, however, that embryoid bodies provide the appropriate microenvironment and necessary factors to support an extensive erythroid differentiation program similar to that seen in vivo. Our results also provide support for the hypothesis that the embryonic to fetal switch may be initiated in the yolk sac and that subsequent migration and seeding of the fetal liver by precursor cells allows for the expansion of the fetal/ adult lineages.

Transfection of human globin genes into ES cells and subsequent differentiation to form embryoid bodies demonstrate that the ES system offers a good in vitro system in which to examine the conserved elements conferring stage specificity of globin gene expression. Although the erythropoietic cells within an embryoid body constitute only a very small proportion of the total cell number, there is a sufficient number of cells to detect the transfected human globin mRNA, when placed under the control of the $\beta$-globin DCR. This region has been shown to confer high-level erythroid-specific $\beta$ globin expression in cultured cells as well as position insensitivity and copy number dependence in transgenic animals (Grosveld et al. 1987; Blom van Assendelft et al. 1989|. We observed the same type of expression for the human $\epsilon$-globin gene in these experiments. More importantly, the correct regulation of the human $\epsilon$-globin gene was preserved, with the temporal pattern of human $\epsilon$ globin activation resembling $\epsilon_{y}$, although activated slightly earlier than $\epsilon_{\mathrm{y}}$ (Fig. 4) in the mouse/embryoid body context. On the basis of sequence homology, the human $\epsilon$ gene is thought to be more closely related to the $\epsilon_{\mathrm{y}^{-}}$than the $\beta_{\mathrm{h} 1}$-globin gene (Czelusniak et al. 1982; Hardies et al. 1984), and both occur in the same relative position of their respective loci. The observation that the highest copy number clone $\epsilon 2.6$ had depressed levels 
Globin expression in embryoid bodies

of the $\epsilon_{\mathrm{y}}$, but not the $\beta_{\mathrm{hl}}$, relative supports this argument. Therefore, we suggest that the human $\epsilon$-globin and mouse $\epsilon_{\mathrm{y}}$-globin gene are very conserved, but that not all the regulatory regions between have been maintained during evolution.

High expression of single globin transgenes leads to chain imbalance and cell mortality (Grosveld et al. 1987; Talbot et al. 1989). Therefore, clone $\epsilon 2.6$ is perhaps more interesting for the fact that $\beta_{\mathrm{hl}}$ expression is not suppressed, because it suggests that the endogenous $\beta_{h_{1}}$ and $\epsilon_{\mathrm{y}}$-globin genes may be expressed in different populations of cells in this clone. However, only direct visualization of the globin gene products in embryoid bodies can provide strong evidence for or against the existence of distinct $\epsilon_{\mathrm{y}^{-}}$or $\beta_{\mathrm{h} 1^{-}}$-expressing erythroid populations.

As in the case of the human $\epsilon$-globin gene, high-level expression of a $\beta$-globin transgene was observed relative to endogenous levels. Unlike the human $\epsilon$-globin gene, however, the pattern of expression was not as clear: The onset of high-level human $\beta$-globin expression correlated with that of the $\epsilon_{\mathrm{y}}$ gene, whereas at later time points, it followed its murine homolog $\beta_{\text {mai }}$, as demonstrated by the expression of $\beta_{\text {maj }}$ (Fig. 5). Although low levels of yolk sac-derived $\beta_{\mathrm{maj}}$-expressing cells can be found in vivo at $\sim 12$ days postcoitum (p.c.) during normal ontogeny (Brotherton et al. 1979), the early high human $\beta$-globin expression observed in these embryoid bodies and the absence of detectable $\beta_{\mathrm{maj}}$ (at days 9 and 12 ) suggests that this may represent aberrant expression. We conclude that this aberrant expression is the result of the minilocus and the absence of the other human globin genes, which affects the expression of the $\gamma$ - and $\beta$-globin genes when expressed in cell lines or transgenic mice; $\gamma$-globin expression is extended to later stages, and $\beta$-globin expression already starts at the embryonic stage (Blom van Assendelft et al. 1989; Behringer et al. 1990; Enver et al. 1990). This phenomenon has led to the proposal that the $\gamma$ - and $\beta$-globin genes are regulated, at least in part, by competition in analogy to the original proposal for the chicken globin genes (Choi and Engel 1988). Our data show clearly that in this regard, the $\epsilon$ globin gene may behave differently from the $\gamma$-globin gene because its expression is not extended to a later stage of development, and we conclude that the $\epsilon$-globin gene is independent from the other genes in the locus. This independence implies that the gene is inactived permanently at the embryonic to fetal switch in humans, and there is evidence that implicates a role for negative regulatory sequences in this process (Cao et al. 1989; Lamb et al. 1989).

In summary, our data demonstrate that ES cell-derived embryoid bodies provide a good in vitro system to study erythropoiesis and globin gene switching. We are attempting presently to improve the system further by growth of blood island cells on different substrata or feeder layers (Eliason et al. 1979; Allen et al. 1982) and by transplantation of these cells into mice (Hollands 1989; Toles et al. 1989). This should allow us to follow the populations of embryonic cells and their product cells in vivo.

\section{Materials and methods}

\section{ES cell culture and DNA transfection}

Both the CCE-ES and STO-neo /G-418-resistant STO fibroblasts) cell lines used in these experiments were obtained from R. Lovell-Badge. Briefly, the ES cells were maintained routinely in gelatin-coated $10-\mathrm{cm}$ tissue culture dishes (Falcon) on confluent feeder layers of mitotically inactivated STO-neo fibroblasts (Robertson 1987). The standard growth medium used for ES culture consisted of $80 \%$ Dulbecco's modified Eagle medium (DMEM), 20\% FCS supplemented with $0.1 \mathrm{mM}$ 2-mercaptoethanol, $1 \times$ nonessential amino acids, $10 \mathrm{U} / \mathrm{ml}$ penicillin, and $10 \mu \mathrm{g} / \mathrm{ml}$ streptomycin. Medium changes were performed daily, and ES cells reached confluence $2-3$ days after passage at $1: 10$ split ratios. Differentiation of ES cells was carried out essentially as described (Doetschmann et al. 1985). Confluent ES cell cultures were harvested by trypsinization. To remove remaining feeder cells, the harvested cells were triturated by passage through a fine-bore Pasteur pipette to ensure a single cell suspension, and the resulting cell suspension was diluted to an appropriate concentration and replated onto fresh tissue culture dishes with incubation at $37^{\circ} \mathrm{C}$ for $1 \mathrm{hr}$. During this time the bulk of the feeders adhered to the substratum, whereas the ES cells remained in suspension. The purified ES cell suspension was then carefully removed and pelleted by centrifugation for $5 \mathrm{~min}$ at $1000 \mathrm{~g}$. ES cells were then resuspended at a concentration of $1.5 \times 10^{5}$ cells per $\mathrm{ml}$ in ES differentiation medium /consisting of $85 \%$ DMEM, 15\% FCS, $0.1 \mathrm{~mm} \mathrm{2-mer-}$ captoethanol, $10 \mathrm{U} / \mathrm{ml}$ penicillin, and $10 \mu \mathrm{g} / \mathrm{ml}$ streptomycin), and $10-\mathrm{ml}$ aliquots were dispensed into $10-\mathrm{cm}$ bacterial petri dishes, which resulted in 200-400 embryoid bodies per dish. When the time course of globin mRNA induction in embryoid bodies was examined, RNA was prepared from the contents of entire dishes at each time point examined. Differentiating ES cell cultures were maintained at $37^{\circ} \mathrm{C}$ in a humidified $5 \% \mathrm{CO}_{2}$ atmosphere and medium was changed daily. Nonaggregated cells died within the first 5 days of differentiation.

DNA transfection of ES cells was performed by calcium phosphate coprecipitation with $25 \mu \mathrm{g}$ of $P_{v u I}$-linearized plasmid DNA on half-confluent ES cultures (Lovell-Badge 1987). The cultures were then incubated for $24 \mathrm{hr}$ at $37^{\circ} \mathrm{C}$ in $5 \%$ $\mathrm{CO}_{2}$ in the presence of the precipitate, after which they were carefully washed and passaged onto fresh feeder plates. Fortyeight hours later, the ES cultures were placed under selection by the addition of $350 \mu \mathrm{g} / \mathrm{ml} \mathrm{G-418} \mathrm{to} \mathrm{the} \mathrm{medium.} \mathrm{Seven} \mathrm{to}$ ten days later, G-418-resistant ES colonies (1-10 colonies per $10^{6}$ cells) were picked, and individual colonies were dispersed and replated into multiwells. G-418-resistant clones derived in this manner were expanded to the level of $10-\mathrm{cm}$ dishes, at which point they could be stored frozen in liquid $\mathrm{N}_{2}$ prior to analysis.

\section{RNA and DNA isolation and analysis}

RNA from undifferentiated ES cells, or ES cell-derived embryoid bodies, was isolated by the lithium/urea technique (Auffray and Rougeon 1980) and stored frozen at $-70^{\circ} \mathrm{C}$ in DEPCtreated sterile water. RNA was then subjected to S1 nuclease protection analysis as described (Fraser et al. 1990). For Northern blot analysis, RNA was fractionated on a denaturing $1 \%$ agarose, $0.66 \mathrm{M}$ formaldehyde gel (Talbot et al. 1989), and blotted onto GeneScreen membrane (New England Nuclear) as per the manufacturer's recommendation. Prehybridization and hybridization were carried out as described (Talbot et al. 1989). Genomic DNA was prepared from the parental ES cells or G-418-resistant ES clones by proteinase $\mathrm{K}$ digestion and 
phenol/chloroform extraction. DNA $(10 \mu \mathrm{g})$ was then digested with the appropriate restriction enzyme(s), fractionated by electrophoresis on $0.6 \%$ agarose gels, and capillary-blotted and hybridized as described (Southern 1975). Blots were washed to high stringency $\left(0.1 \times \mathrm{SSC}, 0.1 \% \mathrm{SDS}\right.$ at $\left.65^{\circ} \mathrm{C}\right)$ and exposed to $\mathrm{X}$-ray film with intensifying screens at $-70^{\circ} \mathrm{C}$.

\section{DNA labeling}

For S1 nuclease protection analyses, probes were either end-labeled by T4 polynucleotide kinase and $\left[\gamma^{-32} \mathrm{P}\right]$ ATP (sp. act. 3000 $\mathrm{Ci} / \mathrm{mmole}$; New England Nuclear) or by fill-in with reverse transcriptase and the appropriate $\alpha^{-32}$-labeled nucleotide triphosphate (sp. act. $3000 \mathrm{Ci} / \mathrm{mmole}$, New England Nuclear) as described (Sambrook et al. 1989). Specific activities of the labeled probes were estimated by Cerenkov counting of labeled probes bound to DE 81 (Whatman) filter discs (Sambrook et al. 1989|. Uniformly labeled probes for Southern or Northern blot analysis were labeled to high specific activity $\left(>10^{8} \mathrm{dpm} / \mathrm{ng}\right)$ by the ramdom primer technique (Feinberg and Vogelstein 1983).

\section{Acknowledgments}

We are grateful to Susan Sword for her assistance in tissue culture, Emma Whitelaw for sending us the $\zeta$ probe, and Dave Greaves and Niall Dillon for helpful advice on the manuscript. M.L. was supported by Fonds de Recherche en Santé de Quebec. This work was supported by the Medical Research Council (UK).

\section{References}

Allen, T.D. and T.M. Dexter. 1982. Ultrastructural aspects of erythropoietic differentiation in long-term bone marrow culture. Differentiation 21: 86-94.

Auffray, C. and F. Rougeon. 1980. Purification of mouse immunoglobulin heavy-chain messenger RNAs from total myeloma tumour RNA. FEBS 107: 303-314.

Bakken, A., G. Morgan, B. Sollner-Webb, J. Roan, S. Busby, and R.H. Reeder. 1982. Mapping of transcription initiation and termination signals on Xenopus laevis ribosomal DNA. Proc. Natl. Acad. Sci. 79: 56-60.

Behringer, R.R., T.M. Ryan, R.D. Palmiter, R.L. Brinster, and T.M. Townes. 1990. Human $\gamma$ - to $\beta$-globin gene switching in transgenic mice. Genes Dev. 4: 380-388.

Blom van Assendelft, G., O. Hanscombe, F. Grosveld, and D.R. Greaves. 1989. The $\beta$-globin dominant control region activates homologous and heterologous promoters in a tissuespecific manner. Cell 56: 969-977.

Borghese, E. 1959. The present state of research on WW mice. Acta. Anatom. 36: 185-203.

Brotherton, T.W., D.H.K. Chui, J. Gauldie, and M. Patterson. 1979. Hemoglobin ontogeny during normal mouse fetal development. Proc. Natl. Acad. Sci. 76: 2853-2857.

Cao, S-X., P.D. Gutman, P.G. Dave, and A.N. Schechter. 1989. Identification of a transcriptional silencer in the 5 -flanking region of the human $\mathrm{e}$-globin gene. Proc. Natl. Acad. Sci. 86: $5306-5309$.

Chada, K., J. Magram, K. Raphael, G. Radice, E. Lacy, and F. Costantini. 1985. Specific expression of a foreign $\beta$-globin gene in erythroid cells of transgenic mice. Nature 314: $377-$ 380 .

Choi, O-R.B. and J.D. Engel. 1988. Developmental regulation of $\beta$-globin switching. Cell 55: 17-26.

Czelusniak, J., M. Goodman, D. Hewell-Emmett, M.L. Weiss, P.J. Venta, and R.E. Tashian. 1982. Phylogenetic origins and adaptive evolution of avian and mammalian haemoglobin genes. Nature 298: 297-300.

deBoer, E., M. Antoniou, V. Mignotte, L. Wall, and F. Grosveld. 1988. The human $\beta$-globin gene promoter; nuclear protein factors and erythroid-specific induction of transcription. EMBO I. 7: 4203-4212.

Doetschman, T. C., H. Eistetter, M. Katz, W. Schmidt, and R. Kemler. 1985. The in vitro development of blastocyst-derived embryonic stem cell lines: Formation of visceral yolk sac, blood islands, and myocardium. I. Embryol. Exp. Morph. 87: 27-45.

Eliason, J.F., N.G. Testa, and T.M. Dexter. 1979. Erythropoietin-stimulated erythropoiesis in long-term bone marrow culture. Nature 281: 382-384.

Enver, T., N. Raich, A.J. Ebens, T. Papayannopoulou, F. Costantini, and G. Stamatoyannopoulos. 1990. Developmental regulation of human fetal-to-adult globin gene switching in transgenic mice. Nature 344: 309-313.

Evans, M.J. and M.H. Kaufman. 1981. Establishment in culture of pluripotential cells from mouse embryos. Nature 292: $154-156$.

Evans, T., M. Reitman, and G. Felsenfeld. 1988. An erythrocyte-specific DNA-binding factor recognizes a regulatory sequence common to all chicken globin genes. Proc. Natl. Acad. Sci. 85: 5976-5980.

Fantoni, A., A. de la Chapelle, R.A. Rifkind, and P.A. Marks. 1968. Erythroid cell development in fetal mice: Synthetic capacity for different proteins. \%. Mol. Biol. 33: 79-91.

Fantoni, A., A. de la Chapelle, and P.A. Marks. 1969. Synthesis of embryonic hemoglobins during erythroid cell development in fetal mice. J. Biol. Chem. 244: 675-681.

Fantoni, A.A., A. Bank, and R.A. Marks. 1967. Globin composition and synthesis of hemoglobins in developing fetal mice erythroid cells. Science 157: 1327-1329.

Farace, M.G., B.A. Brown, G. Raschella, J. Alexander, R. Ganbaci, A. Fantoni, S.C. Hardies, C.A. Hutchinson III, and M.H. Edgell. 1984. The mouse $\beta$ hl gene codes for the $z$ chain of embryonic hemoglobin. 1. Biol. Chem. 259: 71237128.

Feinberg, M.P. and B. Vogelstein. 1983. A technique for radiolabelling DNA restriction fragments to high specific activity. Anal. Biochem. 132: 6-13.

Fraser, P., J. Hurst, P. Collis, and F. Grosveld. 1990. Each of the DNase I hypersensitive sites of the human $\beta$-globin dominant control region directs position-independent expression. Nucleic Acids Res. 18: 3503-3508.

Gossler, A., T. Doetschman, R. Korn, E. Serfling, and R. Kemler. 1986. Transgenesis by means of blastocyst-derived embryonic stem cell lines. Proc. Natl. Acad. Sci. 83: 90659069.

Grosveld, F., G. Blom van Assendelft, D.R. Greaves, and G. Kollias. 1987. Position-independent, high-level expression of the human $\beta$-globin gene in transgenic mice. Cell 51: $975-985$.

Hanscombe, O., M. Vidal, J. Kaeda, L. Luzzatto, D.R. Greaves, and F. Grosveld. 1989. High-level, erythroid-specific expression of the human $\alpha$-globin gene in transgenic mice and the production of human hemoglobin in murine erythrocytes. Genes Dev. 3: 1572-1581.

Hansen, J.N., D.A. Konkel, and P. Leder. 1982. The sequence of a mouse embryonic $\beta$-globin gene. $/$. Biol. Chem. 257: $1048-1052$.

Hardies, S.C., M.H. Edgell, and C.A. Hutchison, III. 1984. Evolution of the mammalian $\beta$-globin gene cluster. J. Biol. Chem. 259: 3748-3756.

Hollands, P. 1987. Differentiation and grafting of haemopoietic stem cells from early postimplantation mouse embryos. $D e$ - 
velopment 99: 69-76.

Jahn, C.L., C.A. Hutchison III, S.J. Phillips, S. Weaver, N.L. Haigwood, C.F. Voliva, and M.H. Edgell. 1980. DNA sequence organization of the $\beta$-globin complex in the BALB/c mouse. Cell 21: 159-168.

Konkel, D.A., J.V. Maizel, Jr. P. Leder. 1979. The evolution and sequence comparison of two recently diverged mouse chromosomal $\beta$-genes. Cell 18: 865-873.

Kovach, J.S., P.A. Marks, E.S. Russell, and H. Epler. 1967. Erythroid cell development in fetal mice: Ultrastructural characteristics and hemoglobin synthesis. J. Mol. Biol. 25: 131142.

Lamb, P., P. Watt, and N.J. Proudfoot. 1989. Negative regulation of the human embryonic globin genes $\zeta$ and $\epsilon$. In Hemoglobin switching, part A: Transcriptional regulation led. G. Stamatoyonnopoulos and A.W. Nienhuis), pp. 269-277. Alan R. Liss, New York.

Leder, P., J.N. Hansen, D. Konkel, A. Leder, Y. Nishioka, and C. Talkington. 1980. Mouse globin system: A functional and evolutionary analysis. Science 209: 1336-1342.

Lovell-Badge, R. 1987. Introduction of DNA into embryonic stem cells. In Teratocarcinomas and embryonic stem cells: A practical approach (ed. E.J. Robertson), pp. 153-182. IRL Press, Oxford/Washington D.C.

Martin, G.R. 1981. Isolation of a pluripotent cell line from early mouse embryos cultured in medium conditioned by teratocarcinoma stem cells. Proc. Natl. Acad. Sci. 78: 7634-7638.

Martin, D.I.K., L.I. Zon, G. Mutter, and S.H. Orkin. 1990. Expression of an erythroid transcription factor in megakaryocytic and mast cell lineages. Nature 344: 444-447.

Peschle, C., F. Mavilio, A. Care, G. Migliaccio, A.R. Migliaccio, G. Salvo, P. Samoggia, S. Petti, R. Guerriero, M. Marinucci, D. Lazzaro, G. Russo, and G. Mastroberardino. 1985. Haemoglobin switching in human embryos: Asynchrony of $\zeta \rightarrow \alpha$ - and $\zeta \rightarrow \gamma$-globin switches in primitive and definitive erythropoietic lineage. Nature 313: 235-238.

Poncz, M., P. Henthorn, C. Stoeckert, and S. Surrey. 1989. Globin gene expression in hereditary persistence of fetal hemoglobin and $(\delta \beta)^{\circ}$ thalassemia. In Oxford surveys on eukaryotic genes (ed. N. Maclean). Oxford University Press.

Rifkind, R.A., D. Chui, and H. Epler. 1969. An ultrastructure study of early morphogenetic events during the establishment of fetal hepatic erythropoiesis. I. Cell Biol. 40: 343365.

Robertson, E.J. 1987. Embryo-derived stem cell lines. In Teratocarcinomas and embryonic stem cells: A practical approach (ed. E.J. Robertson), pp. 71-112. IRL Press, Oxford/Washington D.C.

Romeo, P.-H., M.-H. Prandini, V. Joulin, V. Mignotte, M. Prenant, W. Vainchenker, G. Marguerie, and G. Uzan. 1990. Megakaryocytic and erythrocytic lineages share specific transcription factors. Nature 344: 447-449.

Sambrook, J., E.F. Fritsch, and T. Maniatis. 1989. Molecular cloning: A laboratory manual. Cold Spring Harbor Laboratory Press, Cold Spring Harbor, New York.

Southem, E.M. 1975. Detection of specific sequences among DNA fragments separated by gel electrophoresis. I. Mol. Biol. 98: $503-517$.

Talbot, D., P. Collis, M. Antoniou, M. Vidal, F. Grosveld, and D.R. Greaves. 1989. A dominant control region from the human $\beta$-globin locus conferring integration site-independent gene expression. Nature 338: 352-355.

Toles, J.F., D.H.K. Chui, L.W. Belbeck, E. Starr, and J.E. Barker. 1989. Hemopoietic stem cells in murine embryonic yolk sac and peripheral blood. Proc. Natl. Acad. Sci. 86: 7456-7459.

Wall, L., E. deBoer, and F. Grosveld. 1988. The human $\beta$-globin gene $3^{\prime}$ enhancer contains multiple binding sites for an erythroid specific protein. Genes Dev. 2: 1089-1100.

Whitelaw, E., P. Lamb, P. Hogben, and N.J. Proudfoot. 1989. The globin switch at the level of mRNA in the developing mouse. In Hemoglobin switching, part A: Transcriptional regulation (ed. G. Stamatoyonnopoulos and A.W. Nienhuis), pp. 323-333. Alan R. Liss, New York. 


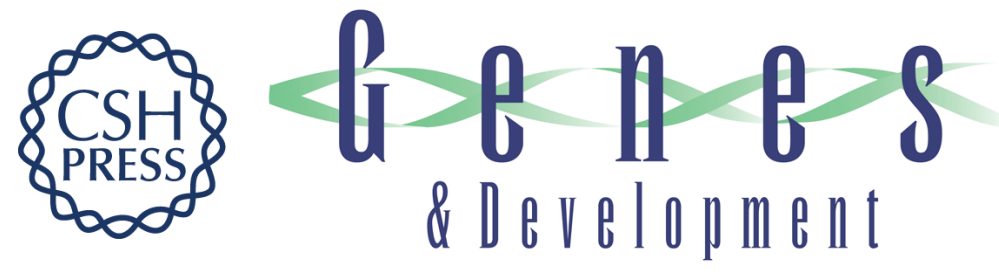

\section{An in vitro globin gene switching model based on differentiated embryonic stem cells.}

$\mathrm{MH}$ Lindenbaum and F Grosveld

Genes Dev. 1990, 4:

Access the most recent version at doi:10.1101/gad.4.12a.2075

References This article cites 42 articles, 18 of which can be accessed free at:

http://genesdev.cshlp.org/content/4/12a/2075.full.html\#ref-list-1

License

Email Alerting Receive free email alerts when new articles cite this article - sign up in the box at the top Service right corner of the article or click here.

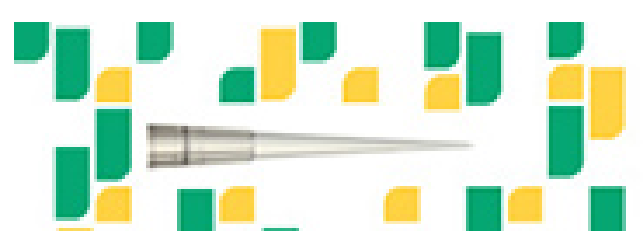

Focused on your science. 